\title{
Front Matter: Volume 8370
}

, "Front Matter: Volume 8370," Proc. SPIE 8370, Fiber Optic Sensors and Applications IX, 837001 (6 June 2012); doi: 10.1117/12.977879

SPIE Event: SPIE Defense, Security, and Sensing, 2012, Baltimore, Maryland, SPIE. United States 


\title{
PROCEEDINGS OF SPIE
}

\section{Fiber Optic Sensors and Applications IX}

\author{
Henry H. Du \\ Gary Pickrell \\ Eric Udd \\ Jerry J. Benterou \\ Alexis Mendez \\ Stephen J. Mihailov \\ Anbo Wang \\ Editors
}

26-27 April 2012

Baltimore, Maryland, United States

Sponsored and Published by

SPIE

Volume 8370 
The papers included in this volume were part of the technical conference cited on the cover and title page. Papers were selected and subject to review by the editors and conference program committee. Some conference presentations may not be available for publication. The papers published in these proceedings reflect the work and thoughts of the authors and are published herein as submitted. The publisher is not responsible for the validity of the information or for any outcomes resulting from reliance thereon.

Please use the following format to cite material from this book:

Author(s), "Title of Paper," in Fiber Optic Sensors and Applications IX, edited by Henry H. Du, Gary Pickrell, Eric Udd, Jerry J. Benterou, Alexis Mendez, Stephen J. Mihailov, Anbo Wang, Proceedings of SPIE Vol. 8370 (SPIE, Bellingham, WA, 2012) Article CID Number.

ISSN 0277-786X

ISBN 9780819490483

Published by

SPIE

P.O. Box 10, Bellingham, Washington 98227-0010 USA

Telephone +1 3606763290 (Pacific Time) · Fax +1 3606471445

SPIE.org

Copyright (C) 2012, Society of Photo-Optical Instrumentation Engineers

Copying of material in this book for internal or personal use, or for the internal or personal use of specific clients, beyond the fair use provisions granted by the U.S. Copyright Law is authorized by SPIE subject to payment of copying fees. The Transactional Reporting Service base fee for this volume is $\$ 18.00$ per article (or portion thereof), which should be paid directly to the Copyright Clearance Center (CCC), 222 Rosewood Drive, Danvers, MA 01923. Payment may also be made electronically through CCC Online at copyright.com. Other copying for republication, resale, advertising or promotion, or any form of systematic or multiple reproduction of any material in this book is prohibited except with permission in writing from the publisher. The CCC fee code is $0277-786 \mathrm{X} / 12 / \$ 18.00$.

Printed in the United States of America.

Publication of record for individual papers is online in the SPIE Digital Library.

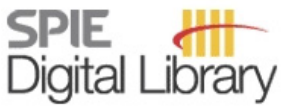

SPIEDigitalLibrary.org

Paper Numbering: Proceedings of SPIE follow an e-First publication model, with papers published first online and then in print and on CD-ROM. Papers are published as they are submitted and meet publication criteria. A unique, consistent, permanent citation identifier (CID) number is assigned to each article at the time of the first publication. Utilization of CIDs allows articles to be fully citable as soon as they are published online, and connects the same identifier to all online, print, and electronic versions of the publication. SPIE uses a six-digit CID article numbering system in which:

- The first four digits correspond to the SPIE volume number.

- The last two digits indicate publication order within the volume using a Base 36 numbering system employing both numerals and letters. These two-number sets start with $00,01,02,03,04$, $05,06,07,08,09,0 A, 0 B \ldots 0 Z$, followed by 10-1Z, 20-2Z, etc.

The CID number appears on each page of the manuscript. The complete citation is used on the first page, and an abbreviated version on subsequent pages. Numbers in the index correspond to the last two digits of the six-digit CID number. 


\section{Contents}

vii Conference Committee

\section{SESSION 1 KEYNOTE}

837002 Photonic crystal fibers and applications in sensing (Keynote Paper) [8370-01]

B. J. Mangan, OFS Fitel, LLC (United States)

\section{SESSION 2 SENSOR DESIGN AND MODELING}

837003 Long-period gratings in photonic crystal fibers operating near the phase-matching turning point for evanescent chemical and biochemical sensing (Invited Paper) [8370-02]

J. Kanka, Institute of Photonics and Electronics of the ASCR, v.v.i. (Czech Republic)

837004 Modal reduction in 6-rod bundled single-crystal sapphire photonic crystal fibers [8370-03] N. T. Pfeiffenberger, G. R. Pickrell, Virginia Polytechnic Institute and State Univ. (United States)

837005 Computational design of a strain optic fiber sensor [8370-04]

A. Yarce Botero, Univ. EAFIT (Colombia)

837006 Modeling of low-finesse, extrinsic fiber optic Fabry-Perot white light interferometers [8370-05]

C. Ma, Z. Tian, A. Wang, Virginia Polytechnic Institute and State Univ. (United States)

837007 Computational design of an optic fiber temperature sensor [8370-06]

D. A. Campo Caicedo, Univ. EAFIT (Colombia)

\section{SESSION 3 NOVEL SENSING DEVICES}

837008 Temperature and pressure sensors based on chiral fibers (Invited Paper) [8370-07]

J. Park, M. S. Wlodawski, J. Singer, D. Neugroschl, Chiral Photonics, Inc. (United States);

A. Z. Genack, Chiral Photonics, Inc. (United States) and Queen's College of The City Univ. of New York (United States); V. I. Kopp, Chiral Photonics, Inc. (United States)

837009 Field testing the Raman gas composition sensor for gas turbine operation [8370-08] M. P. Buric, B. T. Chorpening, J. C. Mullen, J. A. Ranalli, S. D. Woodruff, National Energy Technology Lab. (United States)

8370 0A Advanced fiber optic fluorescence turn-on molecular sensor for highly selective detection of copper in water [8370-09]

Y. Chiniforooshan, J. Ma, W. J. Bock, Univ. of Quebec (Canada); W. Hao, Z. Y. Wang,

Carleton Univ. (Canada) 
8370 OB Multimode interference as a tool for fiber sensing (Invited Paper) [8370-10]

J. L. Santos, S. Silva, INESC Porto (Portugal) and Univ. do Porto (Portugal); L. A. Ferreira, F. M. Araújo, O. Frazão, INESC Porto (Portugal)

\section{SESSION 5 ADVANCED SENSORS FOR ENERGY GENERATION}

$8370 \mathrm{OF} \quad$ Advanced fiber optical sensor and instrumentation for power generation industrial monitoring and diagnostics (Invited Paper) [8370-14]

H. Xia, General Electric Global Research (United States)

$8370 \mathrm{OH}$ Design validation of an air cooled turbo generator by using fibre optic sensors in a shop test [8370-16]

T. Bosselmann, M. Willsch, M. Villnow, S. Strack, V. Chernogorski, J. R. Weidner, R. Roeding,

U. Schwanengel, L. Trefflich, Siemens AG (Germany); S. Lindholm, E. Abromitis, Siemens AG

(United States)

8370 Ol Multi-point sensing in gas turbines using fiber-based intrinsic Fabry-Perot interferometers [8370-17]

T. Shillig, C. Ma, D. Hu, Z. Tian, A. Wang, Virginia Polytechnic Institute and State Univ. (United States)

8370 OK Two-wavelength quadrature multipoint detection of partial discharge in power transformers using fiber Fabry-Perot acoustic sensors [8370-19]

B. Dong, Virginia Polytechnic Institute and State Univ. (United States); M. Han, Univ. of Nebraska-Lincoln (United States); A. Wang, Virginia Polytechnic Institute and State Univ. (United States)

\section{SESSION 6 FIBER BRAGG GRATING SENSORS}

$8370 \mathrm{OL}$ Improvements to high-speed monitoring of events in extreme environments using fiber Bragg grating sensors (Invited Paper) [8370-20]

E. Udd, Columbia Gorge Research (United States); J. Benterou, Lawrence Livermore National Lab. (United States)

8370 OM Study of $\pi$-phase-shifted, Fiber Bragg gratings for ultrasonic detection [8370-22] T. Fink, Q. Zhang, W. Ahrens, M. Han, Univ. of Nebraska-Lincoln (United States)

\section{SESSION 7 ADVANCED INTERFEROMETRIC SENSORS}

837000 Specialty optical fiber design for commercial, intrinsic fiber sensors [8370-34]

C. Emslie, Fibercore Ltd. (United Kingdom) 
8370 OP Performance limitations of a white light extrinsic Fabry-Perot interferometric displacement sensor [8370-25]

E. A. Moro, Univ. of California, San Diego (United States) and Los Alamos National Lab.

(United States); M. D. Todd, Univ. of California, San Diego (United States); A. D. Puckett, Los Alamos National Lab. (United States)

8370 OR Mach-Zehnder interferometer for movement monitoring [8370-27]

V. Vasinek, J. Cubik, S. Kepak, J. Doricak, J. Latal, P. Koudelka, Technical Univ. of Ostrava (Czech Republic)

8370 OS Fiber Fizeau interferometer for remote passive sensing [8370-28]

J. Bush, K. Suh, Optiphase, Inc. (United States)

8370 OT Interferometric polymer optical sensor for intravascular optoacoustic imaging [8370-29] D. Gallego, H. Lamela, Univ. Carlos III de Madrid (Spain); M. Wang, Univ. of Oulu (Finland); J. Hiltunen, VTT Technical Research Ctr. of Finland (Finland); M. Kinnunen, R. Myllylä, Univ. of Oulu (Finland)

\section{POSTER SESSION}

8370 OU Improving the in-flight security by employing seat occupancy sensors based on Fiber Bragg grating technology [8370-30]

H. Zhang, Univ. of Massachusetts Lowell (United States); P. Wang, Polytechnic Institute of New York Univ. (United States)

8370 OV Implement an adjustable delay time digital trigger for an NI data acquisition card in a high-speed demodulation system [8370-31]

H. Zhang, Univ. of Massachusetts Lowell (United States); L. Fan, Stevens Institute of Technology (United States); P. Wang, Polytechnic Institute of New York Univ. (United States); S.-W. Park, Stevens Institute of Technology (United States)

$8370 \mathrm{OW} \quad$ Sound detection monitoring in the transformer oil using fiber optic sensor [8370-32] J. Lee, Andong National Univ. (Korea, Republic of)

Author Index 
Proc. of SPIE Vol. $8370837001-6$

Downloaded From: https://www.spiedigitallibrary.org/conference-proceedings-of-spie on 26 Apr 2023 Terms of Use: https://www.spiedigitallibrary.org/terms-of-use 


\title{
Conference Committee
}

\author{
Symposium Chair
}

Kevin P. Meiners, Office of the Secretary of Defense (United States)

Symposium Cochair

Kenneth R. Israel, Lockheed Martin Corporation (United States)

Conference Chairs

Henry H. Du, Stevens Institute of Technology (United States)

Gary Pickrell, Virginia Polytechnic Institute and State University (United States)

Eric Udd, Columbia Gorge Research (United States)

\section{Conference Cochairs}

Jerry J. Benterou, Lawrence Livermore National Laboratory (United States)

Alexis Mendez, MCH Engineering LLC (United States)

Stephen J. Mihailov, Communications Research Center Canada (Canada)

Anbo Wang, Virginia Polytechnic Institute and State University (United States)

\section{Program Committee}

Christopher S. Baldwin, Aither Engineering, Inc. (United States)

Ole Bang, Technical University of Denmark (Denmark)

Eric A. Bergles, BaySpec, Inc. (United States)

Jeff Bush, Optiphase, Inc. (United States)

Kevin Peng Chen, University of Pittsburgh (United States)

Brian Culshaw, University of Strathclyde (United Kingdom)

Abdessama Elyamani, Northrop Grumman Navigation Systems (United States)

Yoel Fink, Massachusetts Institute of Technology (United States)

Eric Lee Goldner, US Sensor Systems, Inc. (United States)

Tom W. Graver, Micron Optics, Inc. (United States)

Ming Han, University of Nebraska-Lincoln (United States)

Hajime Haneda, National Institute for Materials Science (Japan)

Kazuo Hotate, The University of Tokyo (Japan)

Jiri Kanka, Institute of Photonics and Electronics of the ASCR, v.v.i.

(Czech Republic) 
Victor I. Kopp, Chiral Photonics, Inc. (United States)

Katerina Krebber, Bundesanstalt für Materialforschung und -prüfung (Germany)

Steven T. Kreger, Luna Innovations Inc. (United States)

David A. Krohn, Light Wave Venture Consulting, LLC (United States)

Paul Lefebvre, LxDATA (Canada)

Thomas D. Monte, KVH Industries, Inc. (United States)

Glen A. Sanders, Honeywell Technology (United States)

Dennis J. Trevor, OFS Laboratories (United States)

Xingwei Wang, University of Massachusetts Lowell (United States)

Reinhardt Willsch, Institut für Photonische Technologien e.V. (Germany)

Younan Xia, Washington University in St. Louis (United States)

Hai Xiao, Missouri University of Science and Technology (United States)

\section{Session Chairs}

1 Keynote

Henry H. Du, Stevens Institute of Technology (United States)

2 Sensor Design and Modeling

Polina Pinkhasova, Stevens Institute of Technology (United States)

3 Novel Sensing Devices

Ming Han, University of Nebraska-Lincoln (United States)

$4 \quad$ Photonic Crystal Fiber Sensors

Gary Pickrell, Virginia Polytechnic Institute and State University (United States)

$5 \quad$ Advanced Sensors for Energy Generation

Eric Udd, Columbia Gorge Research (United States)

$6 \quad$ Fiber Bragg Grating Sensors

Fei Tian, Stevens Institute of Technology (United States)

$7 \quad$ Advanced Interferometric Sensors

Jerry J. Benterou, Lawrence Livermore National Laboratory (United States) 